
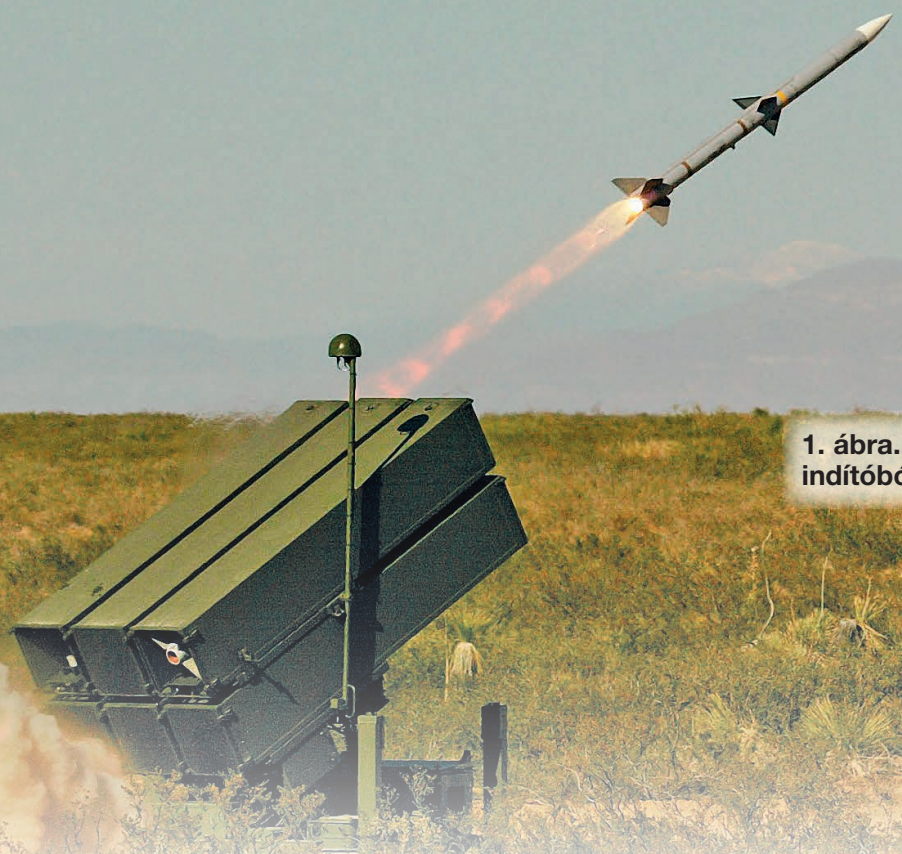

1. ábra. AMRAAM rakéta indítása a harchelyzetbe hozott indítóból (Forrás: Kongsberg Defence \& Aerospace)

Tömböl László* - Böcz Lajos Lóránt** - Juhancsik János***

\title{
A földi telepítésú légvédelem új, kis-közepes hatótávolságú rakétarendszere
}

A Haditechnika folyóirat korábbi számában a szerzők a földi telepítésű légvédelem fejlesztésének első lépcsőjében megvalósuló új, egységszintű vezetési rendszer - a SAMOC (Surface-to-Air Missile Operations Center - Föld-Levegő Rakéta Múveleti Központ) védelemben elfoglalt szerepéről írtak. ${ }^{1}$ Jelen tanulmány a még hadrendben lévő 2K12 Kub komplexumokat váltó NASAMS ${ }^{2}$ beszerzés előzményeit, harcrendi elemeit és publikus képességeit ismerteti meg az olvasókkal.

\section{VISSZATEKINTÉS}

A Magyar Honvédség első, 1959 októberében megalakult - honi rendeltetésű - légvédelmi rakétaezrede ${ }^{3}$ utolsó és egyben valamennyi előző fegyvernemi egység jogutódjának, a 11. Duna Vegyes Légvédelmi Rakétaezrednek a felszámolása 2001. június 30-án lezárult. A szervezet aktív fegyverrendszereit képező Sz-200VE, Sz-75M és Sz-125M komplexumok kivonásával megszűnt a nagy magasságú, valamint a nagy és közepes hatótávolságú önálló légvédelmi rakéta oltalmazási képesség.

A haderőátszervezés - valójában fegyverzetcsökkentés a szárazföldi csapatok [1] közvetlen légvédelmi oltalmazását megvalósító rakétaeszközöket sem kímélte. Elsőként 2000 második félévében a közepes hatótávolságú $2 \mathrm{~K} 11$ Krug, majd ezt követően a közeli hatótávolságú, szovjet Sztrela és Igla rendszereket is kivonták. A hadrendben jelentősen lecsökkentett mennyiségben - csak a 2K12 Kub komplexumok maradtak egyetlen helyőrségbe, az MH 12. Arrabona Légvédelmi Rakétaezredbe összevonva.

A NATO szövetségi csatlakozást követően rendszeresített közeli hatótávolságú francia Mistral magasabb minősé-
ÖSSZEFOGLALÁS: A Zrínyi Honvédelmi és Haderőfejlesztési Program (Zrínyi HHP) keretében a Magyar Honvédség a földi telepitésú légvédelem korszerü, kis és közepes hatótávolságú aktív tűzeszközöket szerez be. Az új rakétarendszer a norvég Kongsberg Defence \& Aerospace és az USA Raytheon Technologies által közösen fejlesztett NASAMS (National Advanced Surface to Air Missile System - Nemzeti Fejlett Felszín-Levegő Rakétarendszer). Ezzel a nemzeti légvédelem a XXI. század szintjén építheti újjá a korábban elvesztett nagy magasságú és közepes hatótávolságú oltalmazási képességét. $\mathrm{A}$ beszerzésre vonatkozó szerződést 2020. november 30-án írták alá a Honvédelmi Minisztériumban, a rendszerbe állítás 2023-ban kezdődik.

KULCSSZAVAK: Zrínyi HHP, földi telepítésủ légvédelem, nemzeti légvédelmi rakétaképesség újraépítése, NASAMS, AMRAAM, Sentinel radar
ABSTRACT: As part of the Zrínyi Defence and Military Development Program the ground based air defence of Hungary will be equipped with a modern short to medium range ground based air defence missile system. The new system is the NASAMS (National Advanced Surface to Air Missile System) engineered and produced by Kongsberg Defence \& Aerospace and US Raytheon Technologies. With this acquisition the ground based air defence of the country will be able to rebuilt its' medium range and high altitude capabilities at the level of the XXI century technology. The acquisition contract was signed at the Hungarian Ministry of Defence on 30th November 2020. The delivery of the new systems will start in 2023.

KEY WORDS: Zrínyi DMDP, Ground Based Air Defence, Rebuilding of the National Air Defence Capability, NASAMS, AMRAAM, Sentinel Radar

\footnotetext{
* Nyugállományú vezérezredes. ORCID: 0000-0003-3289-2296

** Ezredes, az MHP Haderőtervezési Csoportfőnökség Fegyvernemi Képességtervező Főnökség főnöke. ORCID: 0000-0002-4489-331X

*** Nyugállományú alezredes. ORCID: 0000-0002-6333-2729
} 
ge csupán a pontszerủ objektumok védelmében jelentett pozitív változást, de a magasságban és távolságban elvesztett képességek pótlása elmaradt.

A fenti döntések szakmai helyességét szerencsére nem kellett a gyakorlatban sem igazolni, sem pedig megcáfolni. Mindenesetre tény, hogy a NATO Szerbia elleni akciója során a Kub eredményessége a várttól alaposan elmaradt, és az amerikai légierő egyik F-117A - a köznyelv szerint láthatatlan lopakodó (ténylegesen: kis hatásos visszaverő felületü ${ }^{4}$ [2]) - vadászgépét egy Sz-125 Nyeva rendszer „kényszerítette a földre” 1999. március 27-én [3].

A '60-as évektől fejlesztett szovjet Kub kis hatótávolságú, félaktív önirányítású légvédelmi rakétakomplexumok 1976-tól 1982-ig kerültek a Magyar Honvédség hadrendjébe, két (a rakéták három) modernizált változatában. A rendszer egy célcsatornás, ami azt jelenti, hogy egy üteg (önálló tűzalegység) egyidejűleg csak egy légi célt képes követni és arra rakétát rávezetni, ennek befejezéséig más célra nem tud indítani. Az irányítórendszerek lengyel-magyar együttműködésben megvalósult modernizációjának köszönhetően, részben sikerült teljesíteni a NATO-integráció alapkövetelményeit, ugyanakkor az üzemeltető személyzet áldozatkész munkája sem kompenzálja a fenntartó-javító alkatrészellátási gondokat, és az eszközök morális amortizációját. Az alkalmazási képességet tovább szűkíti a rendelkezésre álló légvédelmi rakéták darabszáma és azok üzemi ideje, amelyeknek adminisztratív módon történő meghoszszabbítása már-már veszélyes lehet. Megítélésünk szerint a 2019. évi Tobruq Legacy NATO-koalíciós gyakorlaton teljesített eredmény - amely szerint minden indított rakéta megsemmisítette a célt - hamis illúzióját kelti annak, hogy a rendszer kivonása tovább lenne halasztható

\section{A BeSZERZÉS ELŐZMÉnYEI}

Az elmúlt 20 év sorra kudarccal végződő fejlesztési elképzelései után 2017 szeptemberében, részben a szerzők személyéhez is köthető kis létszámú csoport kapott megbízást és lehetőséget arra, hogy a Zrínyi Honvédelmi és Haderőfejlesztési Program (Zrínyi HHP) egyik prioritásaként meghatározott, a közepes hatótávolságú, földi telepítésű, légvédelmi rakétaképesség helyreállítása, modernizálása érdekében végezzen helyzetértékelést és tegyen javaslatot. A csoport tevékenységét a haditechnikai fejlesztésekért felelős kormányzati és honvédelmi minisztériumi szervek, továbbá a Magyar Honvédség Parancsnoksága (korábban HM HVK) szervezetei felügyelték és irányították.

A potenciális típusok kiválasztását és képességeik előzetes felmérését nagyban elősegítette az európai hadiipari kiállításokon történő részvétel során az egyes eszközök megtekintése azok fizikai valóságában, illetve a gyártókkal történő közvetlen konzultáció lehetősége. A további hazai és nemzetközi nyílt, több esetben minősített adattartalmú tárgyalások és egyeztetések alapján időszakos és eseti, részletes elemző-összehasonlító kimutatások készültek. A munkacsoport záró előterjesztése - szakmai hátteret képezve a katonai felsővezetői és kormányzati döntéshez - egyaránt tartalmazta a beszerzésre javasolt típusok sorrendiségét és azok eszközmennyiségét.

A Honvédelmi Minisztériumban 2020. november 30-án aláirt szerződés alapján a magyar haderő új, földi telepítésű légvédelmi rakétarendszere a norvég Kongsberg Defence \& Aerospace és az USA Raytheon Technologies által közösen fejlesztett NASAMS jelenleg elérhető legmodernebb verziója lesz. A rendszer fő-, és kiegészítő elemeinek többségét a Kongsberg hadiipari vállalat szállítja, és ugyancsak ez a cég végzi el a rendszerintegrációt. Az alkalmazható légvédelmi rakéták az USA FMS (Foreign Military Sales külföldi katonai értékesítés) szerződés szerint „érkeznek” [4], továbbá a megállapodás rendelkezik egy (a radarrendszerrel összefüggő) úgynevezett közvetlen kereskedelmi értékesítési komponenssel is.

A NASAMS a hagyományos merev-, és forgószárnyas repülőeszközök megsemmisítési képességén túl, olyan légi támadó eszközökkel ${ }^{5}$ szemben is hatékonyan alkalmazható, amelyekkel a jelenlegi légvédelem csak korlátozott képességekkel rendelkezik. [5]

Az új eszközök 2023-ban kezdődő rendszerbe állításával - a Kub-komplexumok egyidejü kiváltása mellett - pótlásra kerül a 20 évvel korábban elvesztett nagy magasságú és közepes hatótávolságú oltalmazási képesség, és a fegyvernem jelenleg egyedüli képviselője, az MH 12. Arrabona Légvédelmi Rakétaezred újjáépítheti a légvédelmi rakétarendszert. Az oltalmazható terület rugalmasan tervezhető, annak mérete és az egyidejüleg tűz alatt tartható célok száma a jelenleginél nagyságrendileg magasabb lesz.

\section{A NASAMS „ELőÉLETE ÉS EVOLÚCIÓJA"}

A NASAMS kifejlesztésének elsődleges célja az volt, hogy olyan új, kis- és közepes hatótávolságú rendszert hozzanak létre, amelybe egyidejűleg az 1980-as, '90-es évek meglévő norvég légvédelmi tüzér és közeli hatótávolságú rakéta fegyverzete is integrálható. Az elképzelés alapját a repülőerők számára korábban megvásárolt és nagy számban rendelkezésre álló AIM-120 AMRAAM (Advanced Medium-Range Air-to-Air Missile - fejlett közepes hatótávolságú levegő-levegő rakéta) képezte. Az eredetileg repülőgép-fedélzeti aktív radarirányítású rakéta földi indítása esetén közelítőleg 1/4 értékre csökkenő hatótávolsága elfogadható értéket jelentett, mivel az 1995-ben elért kezdeti műveleti képességet követő hálózatcentrikus kialakítással megoldották az egyes harcrendi elemek széttagolt elhelyezését. A korábbi légvédelmi rakétakomplexumok alapvető jellemzője volt, hogy az irányító- és indítóberendezések a célkövető-tűzvezető radartól néhány 10 vagy 100 méter távolságra körkörösen, illetve szektorosan helyezkedtek el. A NASAMS felderítőirányító-indító elemek egymáshoz viszonyított távolságát, az integrált híradó-informatikai képesség ennél sokkal tágabb határokban teszi lehetővé. A titkosított rádiókapcsolat 25-30 km távolságban is biztosítja a működést, amely kiegészítő kommunikációs pontokkal, vagy vezetékes WAN (Wide Area Network - nagy kiterjedésű hálózat) -összeköttetés esetén tovább növelhető. A tűzelosztó központok kapcsolatára épülő ún. BNDL (Battalion Net Data Link - zászlóalj-hálózati adatkapcsolat) olyan tűzrendszer ${ }^{6}$ [6] kialakítását teszi lehetővé, amelynek összetétele, földrajzi kiterjedése, harci lehetőségének előzetes felderítése csaknem lehetetlen, és a közvetlen tűzkiváltó eszközök az első rakéták indításáig rejtettek, ezáltal az egyes elemek csapásvédettsége és a rendszer egészének túlélőképessége rendkívül magas.

A rendszeresítést követően 2007-ig további fejlesztéseket hajtottak végre:

- áttérés TCP/IP (Transmission Control Protocol/Internet Protocol (átviteli vezérlő protokoll/internetprotokoll) alapú belső-külső kapcsolati rendszerre;

- Link 16 adatátviteli képesség integrálása;

- egy BNDL-be kapcsolható harcrendi alapelemek számának megnövelése;

- újabb, hardver-szoftver módosított radar (AN/MPQ 64F1 - Sentinel);

- elektrooptikai szenzor képesség kialakítása. 
2019-ig pedig:

- új rakétatípusok (AMRAAM-ER és AIM-9X Block2);

- 5. generációs tüzelosztó központ;

- akár több BNDL egy központi tűzelosztóhoz kapcsolása;

- újabb elektrooptikai szenzor;

- és módosított konténeres indítóberendezés (MK2 típusmegnevezéssel)

rendszerbe illesztése valósult meg.

A NASAMS kategóriájában piacvezető rendszer, Magyarország a 12., egyben 6. NATO alkalmazó ország lesz.

\section{A NASAMS ALAPVETŐ TULAJDONSÁGAI}

- hálózatalapú integrált működés;

- nyitott architektúra és rendkívül rugalmas moduláris rendszerfelépítés;

- mindenféle időjárási körülmények közötti alkalmazhatóság, folyamatos, akár 24 órás műveleti képesség;

- körkörös oltalmazás (egy indítóberendezéssel is);

- több célcsatorna (azonosnak tekinthető a rakéták darabszámával);

- extrém magas tűzsűrüség;

- különböző típusú és hatótávolságú rakéták, amelyek közül több kettős felhasználású;

- a rendszerelemek széttagolt elhelyezési lehetősége;

- magas túlélőképesség és csapásvédettség;

- nagyfokú mobilitás, rövid bontási és telepítési idő;

- komplex titkosított és zavarvédett külső-belső kapcsolati rendszer;

- kis létszámú kezelőállomány;

- teljes NATINAMDS (NATO Integrated Air and Missile Defence System - NATO integrált lég- és rakétavédelmi rendszer) kompatibilitás;

- magában hordozza a fejlesztés további lehetőségeit.

\section{A NASAMS RENDSZERELEMEI}

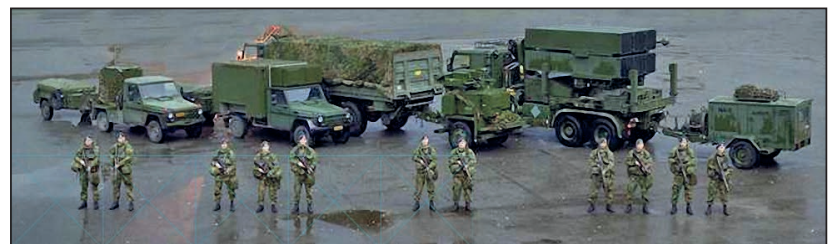

2. ábra. NASAMS fő rendszerelemek és kezelőállomány [7]

\section{A) TÜZELOSZTÓ KÖZPONT \\ - Fire Distribution Center (FDC)}

A tűzelosztó központ önálló vagy BNDL (vezető/végrehajtó) szerepkörben végzi a fegyverrendszer irányítását a közvetlen hozzákapcsolt radar; BNDL esetében a hálózatban müködő radarok által együttesen létrehozott SIAP (Single Integrated Air Picture - egységes integrált légihelyzet-kép), illetve magasabb vezető szervezet RAP (Recognised Air Picture - valós idejű légihelyzet-kép) információi alapján. A bejövő adatokat, a számítógépes javaslatokat és az azt jóváhagyó-felülbíráló kezelői tevékenységet, valamint a rakéták indítását-rávezetését a légvédelmi konzolon két, $75 \mathrm{~cm}$ képátlójú érintőképernyő ábrázolja. $A$ köztes felületen a rendszerbe kapcsolt elemek és azok aktuális állapota látható. További vezérlő-beavatkozó nyomógombos munkafelületek biztosítják az automatikus, félautomatikus és autonóm

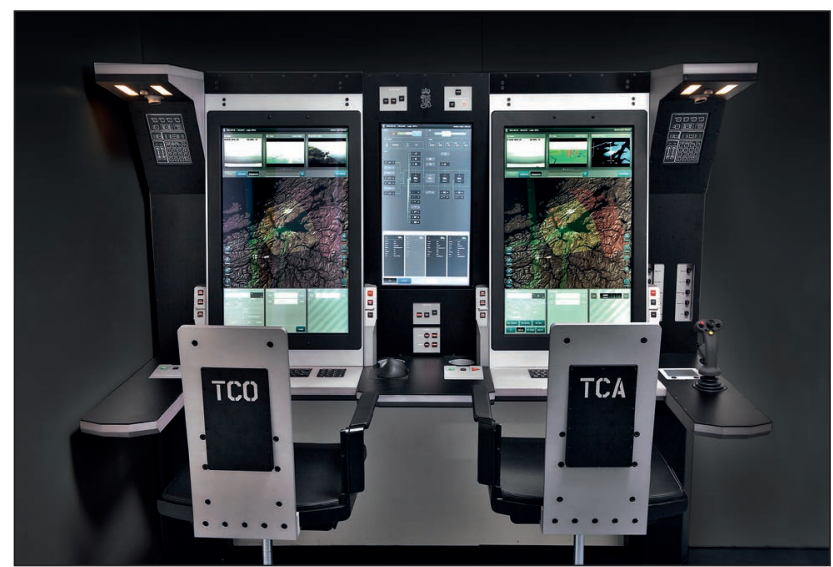

3. ábra. Az 5. generációs FDC belső terének részlete (Forrás: Kongsberg Defence \& Aerospace)

működtetést. Az infokommunikációs elemek beltéri eszközeit is itt helyezik el. (3. ábra)

A komplexum működtető szoftvere a tűzelosztó tiszt számára minden lőesetre ajánlásokat dolgoz ki a beépített, részben a kezelők által korábban lefuttatott gyakorló vagy akár éles lőfeladatok tapasztalata alapján, a gépi tanulás útján létrehozott ún. „tüzelési doktrínának” megfelelően. A szoftver ennek során elvégzi a légi célok besorolását, az optimális elhelyezésű indító, és abban lévő rakétatípus kiválasztását, továbbá az egyéb fontos tüzelés-előkészítési feladatokat.

$A z$ irányító képesség kiterjeszthető hozzákapcsolt VSHORAD (Very Short Range - közeli hatótávolságú) eszközökre (például Mistral) is.

Az FDC (az indítóberendezésen keresztül) pontos célkoordináta-adatokat továbbít a rakéta fedélzetére az indítást közvetlenül megelőzően, és a szükséges pályamódosítások végrehajtásához repülés közben. Online diagnosztikai program felügyeli a rendszermüködést, és rendellenesség esetén riasztja a kezelőket.

A hardvereszközök ISO (International Organization for Standardization - Nemzetközi Szabványügyi Szervezet) -méret szerinti konténerben kapnak helyet, a működés történhet a hordozó járművön vagy hidraulikus emelő szerkezettel földre helyezve is. Az önálló tápellátó és a kommunikációs rendszer antennaszerkezetét a hordozójárműre integrálták. A tartó árbócok emelése és az antennák forgatása elektromos működtetésű.

Kiegészítő tervező szoftver támogatja a harcrendek, az adatkapcsolatok és a manőverek előkészítését. Fiktív légitámadó helyzetbeállításokkal a jövőbeli valós környezetet szimuláló tesztfeladatok futtathatók, amelyek a kezelők felkészítésében döntő fontosságú lehetnek.

\section{B) AN/MPQ-64F1 SENTINEL RADAR}

A Raytheon Technologies által gyártott multifunkciós radar $360^{\circ}$-ban, 20 (30) fordulat/perc forgássebességgel végzi a légtérben tartózkodó eszközök felderítését, idegen-saját azonosítását és a kiválasztott célok követését 3-120 km távolsági tartományban. Keskeny tűnyaláb technológiával és annak kifinomult számítógépes vezérlésével rendkívül pontos háromdimenziós (oldalszög, távolság, magasság) koordinátákat biztosít a kis hatásos visszaverő felületekről is. Korszerü zavarvédelmi technológiákkal rendelkezik, „X” hullámsávú, impulzus Doppler működési elvű. (4. ábra)

Az üzembe helyezés során a 2 fős személyzet végzi a szintezést, az antennapozíció beállítását, az elektromos 


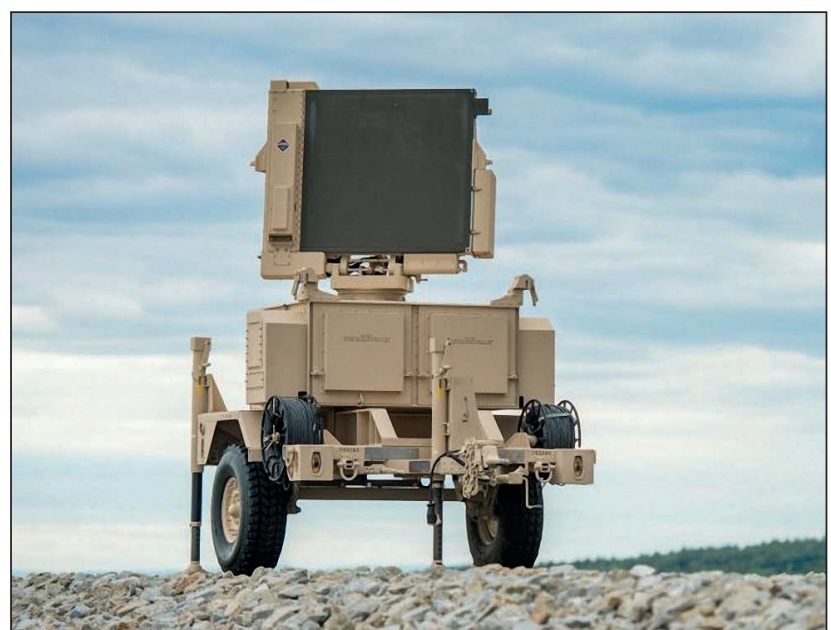

4. ábra. Az AN/MPQ-64F1 Sentinel utánfutóra szerelt változata [7]

táplálás és a vezérlő-jeltovábbító kábelek csatlakoztatását. A bekapcsolást követően a beépített terminálról futtatják a helyi működési tesztet, majd engedélyezik a távvezérlést az irányító FDC számára. Működés közben a radar paraméterei számos integrált funkcióval tovább konfigurálhatók, például a rendelkezésre álló frekvenciák korlátozása, a kisugárzás letiltása meghatározott irányokban vagy kijelölt térrészek intenzív kutatása, teljesítménycsökkentés az automatikus tereptérképezés alapján.

A radar közvetlen vezetékes összeköttetéssel $(\leq 1 \mathrm{~km})$ vagy $30 \mathrm{~km}$-ig terjedő titkosított rádiókapcsolattal csatlakozhat egy tűzelosztó központhoz. A berendezés vontatását olyan jármű végzi, amelyre integrálják a kommunikációhoz szükséges elemeket és a táplálást biztosító áramforrást.

\section{C) KONTÉNERES INDITÓ - CANISTER LAUNCHER}

2019-től új, MK2 típusmegnevezésű konténeres indítóberendezést állatottak rendszerbe ${ }^{7}$ [8]. A korábbi konténerek hosszúságát megnövelték az AMRAAM-ER rakéták méretéhez, átalakították a működést biztosító interfészeket, továbbá a megnövelt tömeghez tartozó statikai módosításokat végeztek. A szállító járműről történő le- és felhelyezést NATO STANAG (Standardization Agreement - Szabványosítási Megállapodás) 2413 szerinti hidraulikus horogemelő szerkezet [9] végzi. (5. ábra) A tápellátásról utánfutón elhe-

\section{5. ábra. A konténeres indító telepítése [7]}

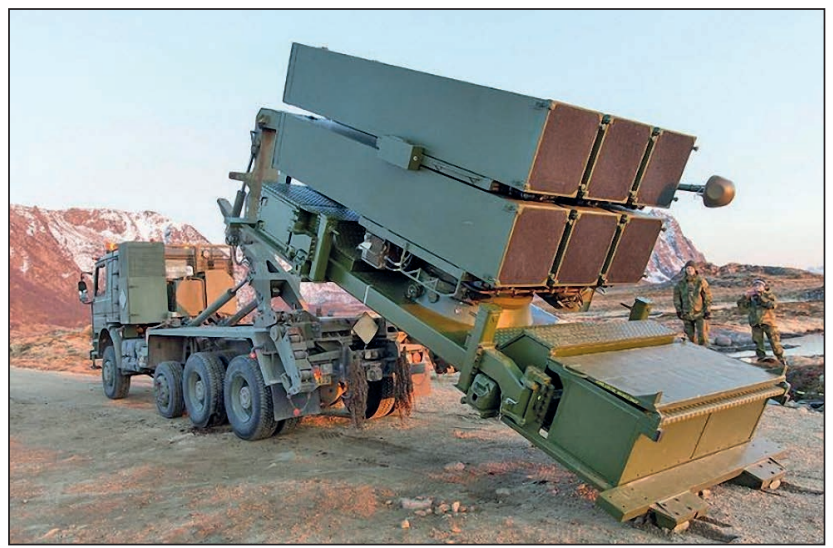

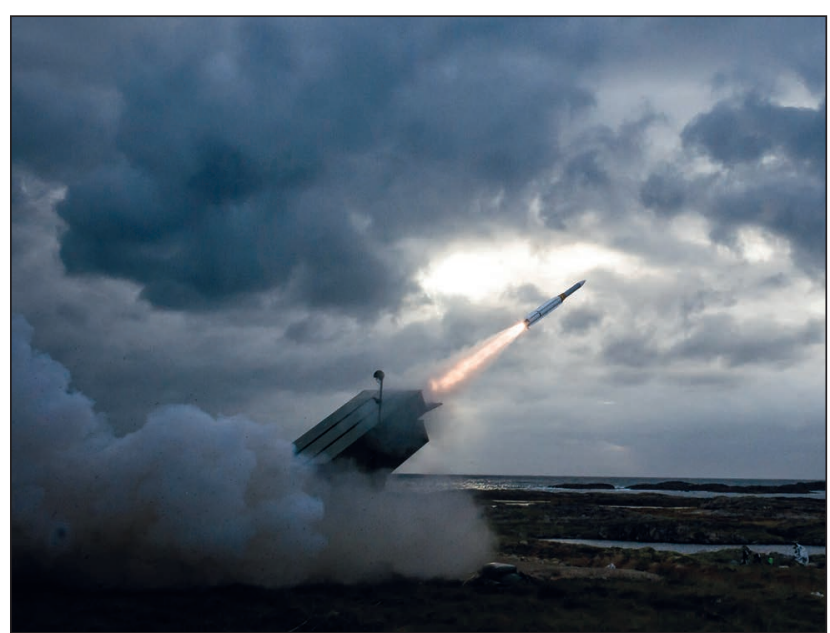

6. ábra. AMRAAM-ER rakéta indítása harchelyzetbe állított indítóból (Forrás: Kongsberg Defence \& Aerospace)

lyezett önálló áramforrás gondoskodik. A hat konténerbe az alkalmazható rakéták tetszőleges típusösszetételben tölthetők be. A típus felismerése és az információ átadása a tüzelosztó központ számára automatikus. Az indító biztosítja a hat rakéta egymástól független célokra történő egyidejü alkalmazását. Az indítás körkörös, $30^{\circ}$-os rögzített helyszögről valósul meg, a minimális ütemidő 2 másodperc.

A telepítés utáni ellenőrzéseket a kezelők egy csatlakoztatható kézi terminálról végzik el. A harchelyzet elérését követően a vezérlést a kapcsolt FDC veszi át. (1. ábra, 6. ábra) Az összeköttetés lehet vezetékes $(\leq 8 \mathrm{~km})$ vagy titkosított rádiócsatorna ( $\leq 25 \mathrm{~km})$.

A külön gépjárműbe telepített indítóberendezés vezetési pont (Launcher Command Post) tartalmazza a kommunikációs rendszerelemeket, továbbá biztosítja a kezelőállomány huzamos idejü távoli elhelyezésének alapfeltételeit.

A konténerek feltölthetők a telepítést megelőzően vagy azt követően. Az indított rakéták pótlása a helyszínre történő kiszállítással, illetve az indítóberendezés központi ellátópontra történő manőverezésével valósul meg.

\section{D) EleKTROOPTIKAI SZENZOR - EleCTRO OPTICAL SENSOR (EOS)}

Az elektrooptikai szenzor opcionális rendszerelem. (7. ábra) A német Rheinmetall cég MSP 600 típusú elektrooptikai eszköze [10] az általános légi/földi helyzet megfigyelésén túl önálló felderítési és célkövetési képességgel is rendel-

\section{7. ábra. Az elektrooptikai szenzor [7]}

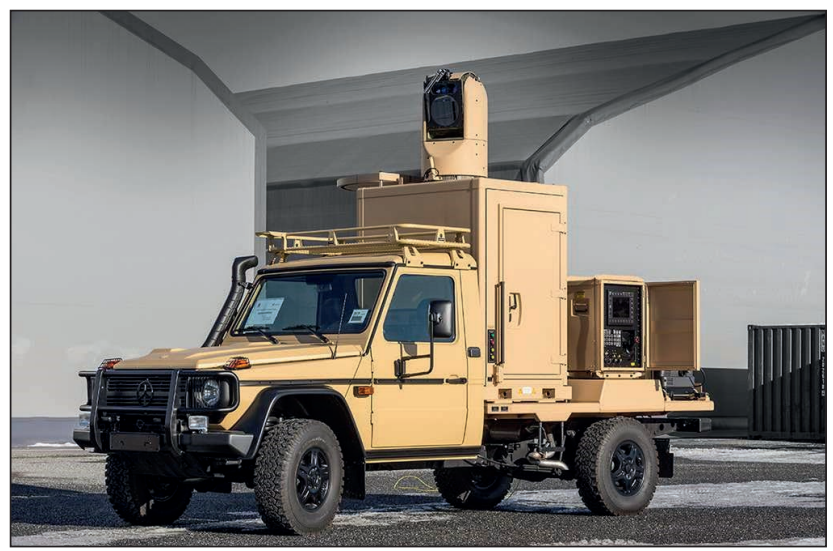


kezik. Az optikai és infravörös képalkotást lézeres távolságmérő egészíti ki. A szenzor önálló jármüre épített, telepítéskor a kameramodul a védett tárolási térből kiemelkedik, oldalszögben és helyszögben mozgathatóvá válik. (7. ábra)

A berendezés közvetlen optikai kábelkapcsolatban van az FDC-vel $(\leq 1 \mathrm{~km})$. A szenzorkép a légvédelmi konzolra kerül, a kameravezérlés nyomógombokkal ellátott botkormányról történik. A képzés és gyakorlás történhet valós és szimulációs helyzetben egyaránt.

\section{E) KIEGÉSZITOOO ELEMEK}

A széttelepítési képesség, ezáltal az oltalmazható terület megnövelése érdekében kiegészítő kommunikációs pontok kapcsolhatók a rendszerbe. Ezen elemek azonosak az AN/MPQ-64F1 radar vontatását és kommunikációját biztosító járművekkel, a hatótávolság-kiterjesztés ennek megfelelően $\leq 30 \mathrm{~km}$. A hozzáférési pont két szerepkörben alkalmazható. Funkcionálhat egyszerű átjátszó reléállomásként és kommunikációs csomópontként. A nagyszámú variációs lehetőség egyedülálló rugalmasságot biztosít redundáns és elosztott hálózat kiépítéséhez.

$A z$ indítókonténerek feltöltését (újratöltését) önálló járművek biztosítják. A rakéták szabványos tároló ládáit a szállító gépkocsi platószerkezetével együtt helyezik az indítóberendezés mellé. Az egyes rakéták mozgatását és az indítópályákra helyezést emelődaru segítségével végzik. Hat rakéta feltöltése, gyakorlott kezelőszemélyzet esetén kevesebb, mint 30 perc alatt biztosítható.

A kezelőállomány költséghatékony felkészítése, képzettségének szinten tartása és fejlesztése érdekében a gyártó komplex gyakorló központot alakított ki, tanterem jellegü beépíthető változatban. A rendszer megfelel egy BNDL tipikus szervezeti felépítésének. Négy darab funkcionálisan működő FDC környezetet tartalmaz, radarok, indítók, EO szenzorok, kommunikációs eszközök valós vagy szimulált használatával. Légitámadó-helyzetek beálításával és valós repülésekkel, fiktív és tervezett harcrendekben nyílik lehetőség a harcászati fogások elsajátítására és új eljárások kifejlesztésére.

Kiegészítő eszközpark gondoskodik a kommunikációs rendszert kezelők képzéséről.

Különálló megfigyelő teremben, projektoros kivetítőn követhető a harci munka, amely a számítógépes rögzítés nyomán, további elemzésre „visszanézhető”.

\section{IRÁNYÍTOTT LÉGVÉDELMI RAKÉTÁK}

A NASAMS több, hatótávolságban, hatómagasságban és célravezetési módjában eltérő megsemmisítő eszközöket alkalmazhat. (8. ábra)

A rendszer kiinduló pontját jelentő AMRAAM továbbra is az alaprakéta. Az elsőként használt AIM-120B típusjelzést követően megvalósult az újabb, "C" sorozat illesztése, amely a magyarországi JAS-39 Gripen többfeladatú harcászati repülőgépek fegyverzetének is része ${ }^{8}$ [13].

A nagyobb távolság-magasság követelmény alapján, a RIM-162 ESSM (eredetileg hajófedélzeti, félaktív radarirányítású rakéta) hajtóművének és az AMRAAM vezérlésének kombinációjával létrehozott AMRAAM-ER változat hatótávolságban mintegy másfélszeres, hatómagasságban pedig 1,7 értékre növelte a képességet. Az új, kizárólag földi indítású rakétát Magyarország másodikként (Katar közel-keleti emírség után) állíthatja rendszerbe.

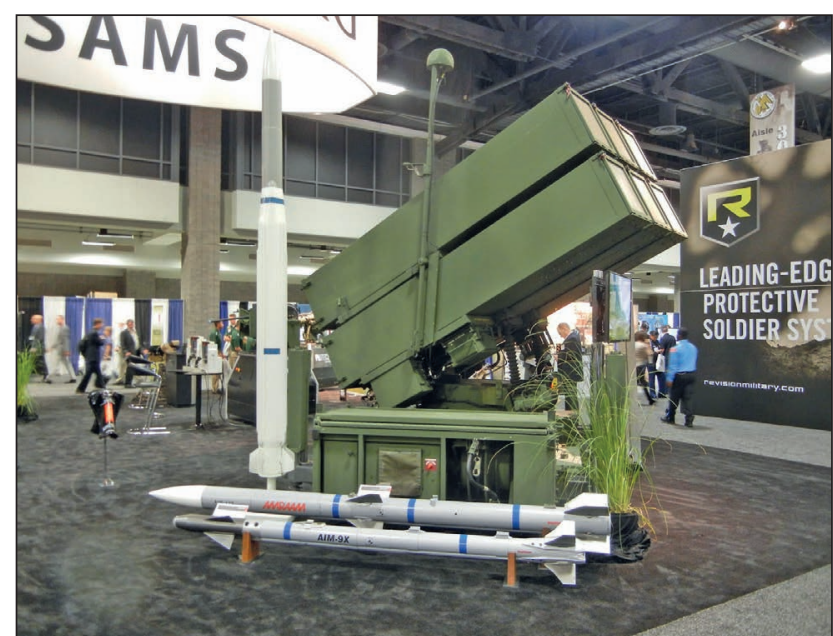

8. ábra. A rakétatípusok a 2015. évi AUSA Annual Meeting kiállításon [12]

További lehetőség az AIM-9X Sidewinder Block2 (szintén kettős felhasználású) infravörös önirányítású rakéta, amely a védelmi képességet közeli hatótávolságban egészítheti ki.

Nyilvánvaló tény, hogy az AIM-120 és az AIM-9X kettős felhasználási lehetősége a kezelés és tárolás, az élettartam, valamint a logisztikai kiszolgálás tekintetében jelentős előnyökkel jár. [11]

\section{NASAMS SZERVEZETI KIALAKÍTÁS ÉS ALKALMAZÁS}

Az önálló felderítő-irányító-megsemmisítő képesség elemei a Sentinel radar, a tűzvezető központ és az indítóberendezés. BNDL szervezeti egységben egyidejüleg 10 radar, 5 FDC, 5 elektrooptikai szenzor és 12 indító múködhet. Az előző minimál-maximál értékek között az elemek tetszőleges mennyisége korlátozás nélkül alkalmazható.

A BNDL tűzlehetőségének meggyőző mutatója, hogy a 12 indítóban elhelyezett 72 db rakéta 72 önáló célra, 20 másodpercen belül indítható.

Kiterjesztett földrajzi elhelyezésben vagy feladat szerint elkülönített több BNDL felsőbb szintű tűzvezetését, a vezető szerepkörrel felruházott FDC vagy a SAMOC végzi.

\section{ÖSSZEGZÉs}

A NASAMS - az első honi légvédelmi rakétaeszközök 1960-as évekbeli magyarországi rendszeresítéséhez hasonlítható - minőségi változást hoz.

Ugyanakkor indokolatlan lenne elhallgatni azt a tényt, hogy egy homogén tulajdonságú rendszer valamennyi jelenlegi és jövőbeni légi fenyegetés elhárítására önállóan nem képes. A ballisztikus rakétákkal szembeni védelem továbbra is a NATINAMDS erre alkalmas, különleges eszközeire hárul mindamellett, hogy a RAM (Rocket, Artillery and Mortar - rakéták, tüzérségi lövedékek és aknagránátok) kategóriájú célok és a kis hatásos visszaverő felületű, pilóta nélküli légi járművek tömeges alkalmazási lehetősége újabb, megoldásra váró kihívásokat jelentenek.

Mindez azt jelenti, hogy a NASAMS rendszerbe állítása mellett a későbbiekben, akár annak továbbfejlesztésével vagy új eszközök beszerzésével, racionális módon és mértékben ki kell terjeszteni a földi telepítésű légvédelmi ké- 
pességet. Ezt deklarálva, a múlt év októberében az Északatlanti Szerződés Szervezete védelmi miniszteri tanácskozásán, szándéknyilatkozatban hazánk is csatlakozott a moduláris földi telepítésű légvédelmi, valamint a gyorsan telepíthető, tűzcsapások elleni fegyverrendszer képességek potenciális közös beszerzésének lehetőségeit vizsgáló szakmai munkacsoportokhoz. [14] Záró aktuális hír, hogy a német Rheinmetall védelmi ipari céggel 2021. május 18-án Budapesten - a stratégiai partnerség bővítése keretében - harcjármüre telepített mobil, közeli hatótávolságú légvédelmi fegyverrendszerek fejlesztéséről és gyártásáról szóló egyetértési nyilatkozat került aláírásra. [15]

\section{HIVATKOZOTT IRODALOM}

[1] Veres Mihály, Légvédelmi Tüzérek és Rakétások, Veszprém: szerzői kiadás, 2002.;

[2] Pártos Sándor, „Kis visszaverő felülettel rendelkező repülőeszközök detektálási lehetőségeinek értékelése" Repüléstudományi Közlemények 26, 2. sz. (2014): p. 565-575. https://folyoirat.ludovika.hu/index.php/ reptudkoz/article/view/4654/3803 (Letöltve: 2021.5.7.);

[3] Zord Gábor László, „Húsz másodperc az élet” Magyar Nemzet, 2010.11.15. https://magyarnemzet. hu/archivum-magyarnemzet/2010/11/huszmasodperc-az-elet (Letöltve: 2021.8.9.);

[4] Defense Security Cooperation Agency, „Hungary - AIM-120C-7 Advanced Medium-range Air-to-air Missiles (AMRAAM)" https://www.dsca.mil/sites/ default/files/mas/hungary_19-25.pdf (Letöltve: 2021.5.7.)

Defense Security Cooperation Agency, „Hungary

- Advanced Medium Range Air-to-Air Missiles Extended Range (AMRAAM-ER)" https://www.dsca. $\mathrm{mil} / \mathrm{sites} /$ default/files/mas/hungary_19-73.pdf (Letöltve: 2021.5.7.);

[5] Draveczki-Ury Ádám, „A Magyar Honvédség pontosan tudja, mit kell venni - Interjú Maróth Gáspárral" Honvédelem.hu, 2020.11. 20. https:// honvedelem.hu/ hirek/a-magyar-honvedseg-pontosan-tudja-mit-kellvenni.html (Letöltve: 2021.5.7.);

[6] A honi légvédelmi rakétacsapatok harcászata, Tankönyv, Budapest: Magyar Néphadsereg, 1982;

[7] Kongsberg, „Nasams Air Defence System” https:// www.kongsberg.com/kda/products/defence-andsecurity/integrated-air-and-missile-defence/ nasams-air-defence-system/ (Letöltve: 2021.5.7);

[8] Army Recognition, „U.S. to deliver Raytheon NASAMS air defense systems to Qatar" https://www. armyrecognition.com/november_2018_global_ defense_security_army_news_industry/u.s._to_ deliver_raytheon_nasams_air_defense_systems_to_ qatar.html Letöltve: 2021.5.7.);
[9] „STANAG-2413 Historical Revision Information” https://www.document-center.com/standards/show/ STANAG-2413/history/REVISION\%204 (Letöltve: 2021.5.7.);

[10] Rheinmetall, „MSP - Multi Sensor Platform” https:// www.rheinmetall-defence.com/en/rheinmetall defence/systems_and_products/c4i_systems/ reconnaissance_and_sensor_systems/multi_sensor_ plattform/index.php (Letöltve: 2021.5.7.);

[11] Air Power Blog, ,Magyarországról Párizsban 2. - lérakos kínálat" https://legiero.blog. hu/2011/06/27/magyarorszagrol_parizsban_2_mi_ lesz_a_lerakkal (Letöltve: 2021.5.7.);

[12] Military Technology, „AUSA 2015: Photographic Recap of the First Two Days" 2015.10.13 http:// www.miltechmag.com/2015/10/ausa-2015photographic-recap-of-first.html (Letöltve: 2021.5.7.);

[13] Kelecsényi István, „A JAS-39C/D Gripen repülőgépek fegyverzete és modernizációs lehetőségei I. rész" Haditechnika 54, 4 sz. (2020): p. 36-40. https:// doi.org/10.23713/HT.54.4.08;

[14] Honvédelem.hu, „Hazánk is csatlakozott a NATO új projektjeihez", 2020.10.23. https://honvedelem.hu/ hirek/hazank-is-csatlakozott-a-nato-uj-projektjeihez. html Letöltve: 2021.5.7.);

[15] Honvédelem.hu, „Magyarország bővíti az együttműködést a Rheinmetall német védelmi ipari óriáscéggel" 2021.5.18. https://honvedelem.hu/hirek/ magyarorszag-boviti-az-egyuttmukodest-arheinmetall-nemet-vedelmi-ipari-oriasceggel.html (Letöltve: 2021.5.25.).

\section{JEGYZETEK}

1 Tömböl László, Böcz Lajos, Juhancsik János, „A földi telepítésú légvédelem új vezetési rendszere” Haditechnika 55, 3. szám pp. 64-69. 2021. https://doi.org/10.23713/HT.55.3.11.

2 NASAMS: National Advanced Surface to Air Missile System - Nemzeti Fejlett Felszín-Levegő Rakétarendszer

3 1992-től a "honi”, illetve a „csapat” előtag már nem szerepelt a légvédelmi szervezetek megnevezésében [1; 175.o.]

4 A hatásos visszaverö felület az elektromos mérettöl - adott frekvenciatartományban - a legtöbb céltárgy esetén erősen függ. Az elektromos méret a $k=2 \pi / \lambda$ hullámszámmal definiálható. [2; 32.o.]

5 Manőverező robotrepülök, személyzet nélküli program vagy távirányítású csapásmérő légi járművek. [5; a szerzők szakmailag kiterjesztett értelmezése szerint

6 Légvédelmi rendeltetésű földi telepítésű, a felderítő, vezető-irányító és aktív tüzeszközök meghatározott földrajzi területen elhelyezett, egységes elgondolás szerint felépített és alkalmazott rendszere. [6; 117.o.; a szerzők módosított megfogalmazása szerint]

7 A rendszerhez kialakítottak egy ún. magas mozgékonyságú (HUMWEE terepjáróra szerelt) indítóberendezést is, de ezt a változatot csak néhány vásárló ország választotta. [8]

8 AIM-120 AMRAAM C-7 integráció: a látóhatáron túli légi harcra alkalmas amerikai rakétát rendszeresítő országok a legújabb „C" változatot is alkalmazhatják a Gripen C/D-ken. [13; 40.o.]

A Haditechnika folyóirat korábbi számai megvásárolhatók:

Líra Könyváruház, Récsei Center 1146 Bp., Istvánmezei út 6., (telefon: 411-1543);

Stúdió könyvesbolt 1138 Bp., Népfürdő u. 15/D, (telefon/fax: 359-1964, 359-6461);

HM Zrínyi Nonprofit Kft. Ügyfélszolgálat (Budapest II., Fillér u. 14.)

Nyitvatartás: H.-P. 9-15 óra ugyfelszolgalat@hmzrinyi.hu. 